Section Editors

David C. Spencer, MD

Steven Karceski, MD

Erik K. St. Louis, MD

\title{
New evidence for reduced leg oxygen levels in restless legs syndrome
}

WHY IS THIS STUDY IMPORTANT? Restless legs syndrome (RLS), also now known as Willis-Ekbom disease (WED), is common and affects about $10 \%$ of the general population. It affects women more than men. RLS/WED causes an uncomfortable urge to move the legs. It is often worse in the evening, especially around bedtime, and is temporarily improved by leg movement.

RLS/WED may be caused by changes in the nerve transmitter dopamine. Dopamine is a signaling molecule that allows nerve cells to communicate with one another in the brain and spinal cord. Changes in dopamine may be linked to low levels of iron in the brain and body along with poor iron transport into the brain and changes in brain dopamine receptors. ${ }^{1}$ However, there is new evidence for problems with blood flow and leg oxygen levels in RLS/WED. These changes involve the cells of the blood vessel walls, or endothelium. These changes include reduced oxygen levels. There is also altered blood flow in the lower leg muscles in patients with RLS/WED. ${ }^{2}$

HOW WAS THE STUDY DONE? In this issue of Neurology ${ }^{\circledR}$, Salminen and colleagues have provided further evidence for altered blood flow in the legs in RLS/WED. ${ }^{3}$ They studied oxygen and carbon dioxide levels using sensors placed on the skin of the legs in 15 patients with RLS/WED and 14 healthy individuals during a "suggested immobilization test" (SIT). The SIT requires the patient to sit in bed for 1 hour on 2 testing sessions ( 2 and 4 hours before bedtime), to avoid moving his or her legs, and to report the severity of RLS/WED symptoms every 5 minutes. The researchers studied the patients with RLS/WED while they were off of their usual RLS/WED medication (pramipexole, a dopamine drug commonly used in RLS/WED treatment, which was stopped at least 2 weeks before study participation) and then when they resumed their pramipexole treatment. Patients with RLS met the standards for diagnosis, and the severity of RLS symptoms was measured by a common study scale. Patients with RLS included 7 women and 8 men with an average age of 57 years who had severe RLS symptoms off of treatment.

WHAT DID THE STUDY SHOW? The investigators showed that reduced leg oxygen levels were strongly associated with RLS symptom severity in untreated patients. They also showed that leg oxygen levels partially improved after dopamine medicine was restarted. ${ }^{3}$ Reduced leg oxygen levels improved when pramipexole treatment was restarted, similar to the effects of leg movement. This suggests that pramipexole may have a treatment effect on leg blood vessels in addition to its actions on brain and spinal cord nerve receptors.

WHAT ARE THE NEXT STEPS? This study by Salminen and colleagues has helped us better understand the problems, but more studies are needed. Low leg oxygen levels in RLS/WED need to be studied. It is possible that improving low leg oxygen levels could be a helpful treatment. This study did not prove that lower leg oxygen actually causes RLS/WED symptoms; it is also possible that lower leg oxygen instead results from the symptoms of RLS/WED. Further research is needed to clarify the direction of this association. Future research will need to determine what causes reduced leg oxygen levels in RLS/ WED at a molecular level. One possible cause may involve nitric oxide (NO), a relaxer of blood vessel walls that may improve blood flow. If it can be shown that problems in NO function occur in RLS/WED, then treatments targeting such problems could potentially improve RLS/WED symptoms. Future laboratory and human studies are also necessary to understand how, when, and where dopamine therapies act in RLS/WED. This could lead to new treatments focused on leg blood vessels that could reduce some of the side effects of RLS medications.

This new evidence helps us better understand RLS/WED and could possibly prompt new medication and nonmedication treatments that focus on improving leg tissue oxygen levels in patients with RLS/WED. ${ }^{4}$

\section{REFERENCES}

1. Dauvilliers Y, Winkelman J. Restless legs syndrome: update on pathogenesis. Curr Opin Pulm Med 2013;19:594-600.

2. St. Louis EK, Ulfberg J. Putting the legs back into restless legs syndrome: new evidence for the microvascular hypothesis. Neurology 2014;82:1850-1851.

3. Salminen AV, Rimpilä V, Polo O. Peripheral hypoxia in restless legs syndrome (Willis-Ekbom disease). Neurology 2014;82:1856-1861.

4. Mitchell UH. Nondrug-related aspect of treating Ekbom disease, formerly known as restless legs syndrome. Neuropsych Dis Treat 2011;7:251-257. 


\section{PATIENT PAGE}

Section Editors

David C. Spencer, MD

Steven Karceski, MD

Erik K. St. Louis, MD

\section{About restless legs syndrome/ Willis-Ekbom disease}

WHAT IS RESTLESS LEGS SYNDROME/WILLISEKBOM DISEASE AND WHO IS LIKELY TO HAVE

IT? Restless legs syndrome (RLS), also now known as Willis-Ekbom disease (WED), affects about 10\% of the general population and is more common in women. Up to $2 \%$ of children are also affected. RLS/WED causes an uncomfortable and irresistible urge to move the legs and can interfere with sleep and quality of life.

WHAT IS THE CAUSE OF RLS/WED? The cause of RLS/WED is unknown. RLS/WED may be either primary or secondary. In primary RLS/WED, symptoms are not associated with other medical conditions. Genetic factors are likely since family history is seen in half of patients. In secondary RLS/WED, the condition is related to other diseases. It may be associated with kidney failure, pregnancy, or peripheral neuropathy.

RLS/WED has also been linked to low brain and body iron levels. This may be a result of changes in brain iron transport and brain nerve transmitter dopamine receptors. ${ }^{1}$ However, recent studies have suggested that reduced leg blood flow may also play a role in RLS/WED symptoms. ${ }^{2,3}$

WHAT ARE THE SYMPTOMS AND HOW IS IT DIAGNOSED? RLS/WED symptoms include an uncomfortable urge to move the legs in the evening or when at rest during the daytime. Symptoms improve with walking or leg movement. Symptoms may interrupt restful sleep. The diagnosis is made by identifying the typical symptoms. Involuntary leg movements called periodic leg movements of sleep (PLMS) occur in about $80 \%$ of patients with RLS/WED, so a common misconception is that a sleep study is necessary for diagnosis. However, PLMS are also frequent in those without RLS/WED. Thus a sleep study is not necessary for diagnosis, although it is often helpful to provide supportive evidence for the condition or to rule out sleep apnea.

ARE THERE PREVENTIVE MEASURES? Studies have shown that regular moderate exercise may reduce RLS/WED symptoms. Also, since RLS/WED symptoms often happen when patients are bored, staying mentally active may prevent or reduce symptoms. Reducing caffeine or certain medications that aggravate RLS symptoms, such as antidepressants (venlafaxine [Effexor] or selective serotonin reuptake inhibitors) or dopamine-blocking medications (prochlorperazine [Compazine] or metoclopramide [Reglan]), may be helpful. Low body iron levels may worsen RLS/WED symptoms. When reduced or low normal ferritin levels are found (a blood test indicating reduced body iron), iron supplements may help.

HOW IS RLS/WED CURRENTLY TREATED? Taking warm (or cool) baths or showers, massage, moderate regular exercise, reduced caffeine, and mentally engaging activities can help relieve mild or intermittent RLS/ WED symptoms. However, when symptoms are more severe and regularly disturb sleep or daytime activities, particularly more than 2-3 days per week, RLS/WED treatment may be prescribed. ${ }^{45}$ Dopamine agonist medications are the most common and successful treatment. These include pramipexole (Mirapex), ropinirole (Requip), and the newer transdermal patch rotigotine (Neupro).

"Augmentation" is an overall worsening of RLS/ WED, with symptoms becoming more intense, occurring earlier in the day, and spreading up to the arms and upper body. This happens over time in half or more of patients with RLS/WED receiving pramipexole or ropinirole. Rotigotine may produce less augmentation. Another common and concerning side effect of the dopamine drugs is impulse control disorder symptoms, such as excessive gambling, shopping, or hoarding behaviors. If these unfortunate symptoms occur, the dopamine drug usually must be stopped. Also useful are the antiseizure and pain medication gabapentin (Neurontin), its derivative gabapentin encarbil (Horizant), and the closely related newer medication pregabalin (Lyrica). Opiate medications, including tramadol (Ultram), oxycodone, and methadone, have also been used in some patients with RLS/WED whose symptoms are difficult to control.

\section{FOR MORE INFORMATION}

AAN Patients and Caregivers site http://patients.aan.com/disorders/index.cfm? event $=$ viewedisorder_id $=1053$

Willis-Ekbom Disease Foundation

http://www.rls.org

National Sleep Foundation

http://sleepfoundation.org/sleep-disorders-problems/ restless-legs-syndrome 


\section{STUDY FUNDING}

The project described was supported by the National Center for Research Resources and the National Center for Advancing Translational Sciences, National Institutes of Health (NIH), through grant 1 UL1 RR024150-01. The content is solely the responsibility of the authors and does not necessarily represent the official views of the NIH.

\section{REFERENCES}

1. Dauvilliers Y, Winkelman J. Restless legs syndrome: update on pathogenesis. Curr Opin Pulm Med 2013;19:594-600.

2. Salminen AV, Rimpilä V, Polo O. Peripheral hypoxia in restless legs syndrome (Willis-Ekbom disease). Neurology 2014;82:1856-1861.
3. St. Louis EK, Ulfberg J. Putting the legs back into restless legs syndrome: new evidence for the microvascular hypothesis. Neurology 2014;82:1850-1851.

4. Silber MH, Becker PM, Earley C, Garcia-Borreguero D, Ondo WG. Medical Advisory Board of the Willis-Ekbom foundation. Willis-Ekbom disease foundation Revised Consensus Statement on the Management of restless legs syndrome. Mayo Clin Proc 2013;88:977-986.

5. St Louis EK. Key sleep neurologic disorders: Narcolepsy, restless legs syndrome/Willis-Ekbom disease, and REM sleep behavior disorder. Neurol Clin Pract 2014;4:16-25. 


\title{
Neurology
}

\author{
New evidence for reduced leg oxygen levels in restless legs syndrome \\ Erik K. St. Louis \\ Neurology 2014;82;e185-e187 \\ DOI 10.1212/WNL.0000000000000513
}

This information is current as of May 26, 2014

\begin{tabular}{|c|c|}
\hline $\begin{array}{l}\text { Updated Information \& } \\
\text { Services }\end{array}$ & $\begin{array}{l}\text { including high resolution figures, can be found at: } \\
\text { http://n.neurology.org/content/82/21/e185.full }\end{array}$ \\
\hline References & $\begin{array}{l}\text { This article cites } 9 \text { articles, } 3 \text { of which you can access for free at: } \\
\text { http://n.neurology.org/content/82/21/e185.full\#ref-list- } 1\end{array}$ \\
\hline Subspecialty Collections & $\begin{array}{l}\text { This article, along with others on similar topics, appears in the } \\
\text { following collection(s): } \\
\text { All Movement Disorders } \\
\text { http://n.neurology.org/cgi/collection/all_movement_disorders } \\
\text { All Sleep Disorders } \\
\text { http://n.neurology.org/cgi/collection/all_sleep_disorders } \\
\text { Restless legs syndrome } \\
\text { http://n.neurology.org/cgi/collection/restless_legs_syndrome }\end{array}$ \\
\hline Permissions \& Licensing & $\begin{array}{l}\text { Information about reproducing this article in parts (figures,tables) or i } \\
\text { its entirety can be found online at: } \\
\text { http://www.neurology.org/about/about_the_journal\#permissions }\end{array}$ \\
\hline Reprints & $\begin{array}{l}\text { Information about ordering reprints can be found online: } \\
\mathrm{http} / / / \mathrm{n} \text {.neurology.org/subscribers/advertise }\end{array}$ \\
\hline
\end{tabular}

Neurology ${ }^{\circledR}$ is the official journal of the American Academy of Neurology. Published continuously since 1951, it is now a weekly with 48 issues per year. Copyright () 2014 American Academy of Neurology. All rights reserved. Print ISSN: 0028-3878. Online ISSN: 1526-632X.

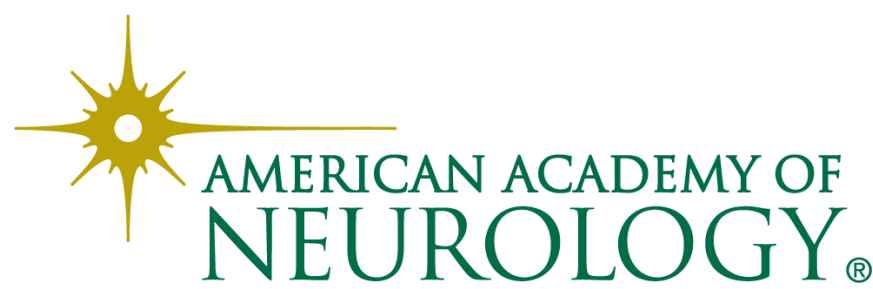

